\title{
AS MULHERES, O DESAPARECIMENTO E A PERDA
}

\author{
Camila Pimentel Freire ${ }^{1}$
}

RESUMO: Este artigo tem como objetivo ressaltar a trajetória de mulheres após o desaparecimento. $\mathrm{O}$ conceito de desaparecimento elaborado tem como elemento central o desconhecimento do paradeiro da pessoa desaparecida por parte do entorno. Elementos como a perda, o vazio e os efeitos provocados pelo desaparecimento são fatores importantes. Pela incerteza inerente ao fenômeno, as mulheres mantêm a esperança de reencontrar a pessoa desaparecida, o que as impossibilita de realizar os processos de luto. Destacam-se, ainda, os movimentos das mulheres na busca pelos seus desaparecidos, que podem ter uma configuração mais individual ou coletiva.

PALAVRAS-CHAVE: Desaparecimento; Mulheres; Busca.

Recebido em: outubro de 2012

Aceito em: abril de 2013

Para citar este artigo:

FREIRE,Camila; As mulheres, o desaparecimento e a perda. In: Revista Intratextos, 2013, vol 4, no1, p. XX.XX. DOI: 10.12957/intratextos.2013.6070

\footnotetext{
${ }^{1}$ Doutoranda do Programa de Pós-Graduação de Ciências Sociais/UERJ. Email: camilapfreire@hotmail.com
} 
O presente trabalho tem como objetivo ressaltar elementos da trajetória de mulheres no processo pós-desaparecimento. Este trabalho é parte do processo de elaboração da tese de doutorado, que ainda se encontra em curso.

Os desaparecimentos políticos são aqueles cometidos em virtude da existência de um projeto político do Estado, que utiliza o desaparecimento como forma de se manter e se legitimar. O Estado é o responsável direto pela produção do desaparecimento e tem como objetivo a eliminação dos seus inimigos políticos. Na tese, o conceito ficará restrito aos desaparecimentos cometidos contra opositores da ditadura militar ${ }^{2}$, embora possa ser trabalhado em outros contextos históricos. O recorte realizado, contudo, não tem como pretensão ignorar os desaparecimentos por motivações políticas, cometidos ao longo da história social brasileira, anteriores à ditadura instalada pelo golpe de 1964.

Os desaparecimentos sem vinculação a um projeto político de Estado serão designados como comuns. Esses desaparecimentos também ocorrem em períodos nos quais não há um cenário político (ditatorial) protagonizado pelo Estado. Portanto, não se estabelece aqui um recorte temporal.

A pesquisa possui como metodologia a realização de entrevistas semi-estruturadas, gravadas e posteriormente transcritas ${ }^{3}$. Foram realizadas 18 entrevistas, com mulheres familiares de desaparecidos comuns e desaparecidos políticos ${ }^{4}$.

As familiares foram indicadas por organizações de defesa dos direitos humanos, e por pessoas próximas, que conheciam a sua situação de familiar de pessoa desaparecida. Após a indicação, as familiares foram contatadas por telefone para consulta sobre a possibilidade de realização da entrevista. As entrevistas de desaparecidos comuns possuem referências do local do desaparecimento, nos locais em que foi possível a hipótese. Nos casos de desaparecidos políticos não há menção ao local do desaparecimento.

\footnotetext{
${ }^{2}$ Acesso em: 28 jul 2012. Disponível em: http://www.leidoshomens.com.br/index.php/noticias/comissao-daverdade-toma-posse-e-sdh-divulga-novo-numero-de-desaparecidos/

${ }^{3}$ Ainda serão analisados dados sobre os desaparecimentos no estado do Rio de Janeiro, como parte da metodologia da pesquisa.

${ }^{4}$ Vale ressaltar que 10 familiares indicadas não aceitaram participar da pesquisa, pois alegaram que preferiam não falar sobre o assunto, extremamente doloroso. Em alguns casos, questionaram se a entrevista resultaria em algum esclarecimento sobre o desaparecimento.
} 
A maioria das familiares de desaparecidos comuns entrevistadas não possui ligação com organizações ou movimentos militantes. As familiares de desaparecidos políticos possuem um histórico de militância ou, em virtude dos processos de reparação pecuniária e simbólica, estão vinculadas às organizações, que acompanham o andamento das ações e pressionam o Estado para adoção de medidas que possam contribuir para o esclarecimento dos desaparecimentos.

De forma breve, serão destacados pontos do processo de apropriação da perda por algumas familiares, e de transformação do seu caso, inicialmente individual, em uma causa pública.

\section{O significado do desaparecimento}

O desaparecimento para as familiares, a princípio, significa a perda, o vazio e a impossibilidade de continuidade da vida. O conceito de desaparecimento elaborado tem como elemento central o desconhecimento do paradeiro da pessoa desaparecida por parte do entorno. Nesse sentido, a não há localização do corpo é o fator que determina a caracterização do desaparecimento, e nesse sentido, a incerteza se a pessoa desaparecida está viva ou morta é inerente ao fenômeno. A ausência do corpo é o aspecto central que diferencia o desaparecimento da morte.

A localização da pessoa desaparecida possibilitaria a realização dos processos de luto e, talvez, explicações sobre o desaparecimento. Ser familiar de desaparecido é conviver com a incerteza que se encontra no bojo do fenômeno desaparecimento.

(...) quando fomos na delegacia, acho que foi na de Cabo Frio, não lembro... aí a mulher dele foi, tinha muita gente acusando ela, que foi ela que tinha caso com esse homem e tinha mandado o cara fazer isso com ele, isso que os vizinhos falaram lá, nunca ficou provado nada (...) Só ela deu depoimento. Ela se defendia, não tinha culpa nenhuma, ele tinha ficado lá porque tava trabalhando, que ela não tinha envolvimento com esse tal cara... olha, eu acho q não, acho q não... então... meus vizinhos que comentavam que ela traía meu irmão com esse cara... e ficou nisso, muitos anos de procura...(Irmã de desaparecido comum de 1997, Cabo Frio).

Ele vinha qualquer hora, não tinha tempo certo, ele vinha, via a gente, falava com a gente, via o que a gente precisava... aí teve um período... 22 de maio... ele saiu, não voltou mais... 1975 (...) aí cadê ele, cadê ele (...) a gente vivia num período tremendo... eu me dei conta logo no começo... uma semana, 15 dias, ele vinha... aí passou um tempo, ele não veio... aí caiu a ficha, né, ninguém entrou em contato com 
a gente não... nem do partido (...) a gente sabe que era assim (...) (Esposa de desaparecido político de 1975).

Os diferentes relatos de possíveis testemunhas podem direcionar as familiares para diferentes órgãos ou estratégias de localização dos seus desaparecidos.

Aí a gente andou, a gente foi pra DPCA, padre Severino, porque falaram que ele tinha sido preso, ai andamos por esses lugares assim. Aí eu encontrei com minha vizinha na rua ela falou. Aí eu fiquei nervosa, fui na minha mãe falar com ela, aí todo rapazinho de costas eu achava que era ele... eu trabalhava na garagem a noite, ai com uniforme a gente podia pegar sem pagar, aí a gente saiu atrás, no mesmo dia, a gente botou papel nas ruas (...) Dois dias depois que eu soube eu fui na DPCA, antes eu andei por lugares que as pessoas falavam que ele podia estar, porque adolescente infrator vai pra lá, fomos em Bangu, Padre Severino... aí falei pra minha mãe marcar encontro com a menina, a menina não foi... (Mãe de desaparecido comum de 2001, Anchieta).

A incerteza pode inclusive gerar questionamentos sobre o tipo de desaparecimento.

eu penso várias coisas... porque já aconteceu de filho de vizinha minha, matarem o menino, enterrarem em qualquer terreno, e a família descobriu, ficou sabendo, aí os bandidos não deixavam a família subir, mas aí tinha parente da polícia, aí entrou em contato com outros PMs, subiram, desenterraram, acharam o corpo deformado, fedido, mas encontraram... eu fui criada de um jeito, não tenho hábito de andar em morro, quer dizer, a gente sem orientação como vamos andar nesses lugares, não tem como... sinceramente eu não sei, ele não era garoto de briga, sempre vivia na dele, não sei, porque as vezes o filho nos surpreende, mas o comportamento tava normal, não notei diferença, algumas semanas depois os amigos falavam onde tava, mas nunca chegaram pra mim e falaram olha, ele tá lá, era só, ah, viram o Thiago não sei aonde, viram ele lá, etc... (Mãe de desaparecido comum de 2001, Anchieta). Grifos meus.

No relato abaixo, embora todos os testemunhos apontem para a ocorrência de um desaparecimento forçado, com uso de violência, o não esclarecimento e os novos elementos trazidos ao processo, alimentam expectativas de encontrar o desaparecido ainda com vida.

(...) de repente você perde a memória com uma pancada na cabeça, não sei... no fundo do meu coração, eu acho que ele tá vivo... eu acho... acho que ele perdeu a memória, sabe, e já não era uma pessoa nova, ele tinha uns 50 anos... há pouco tempo, menos de um ano, a cunhada da minha Irma mora no engenho da rainha e tem uma casa em Iguaba. Eles freqüentam uma igreja que tem um sopão pros mendigos da rua. Aí ela disse que conhece o meu irmão por foto e tudo e disse que tinha uma pessoa muito igual a ele, aí voltou a esperança (Irmã de desaparecido comum de 1997, Cabo Frio).

No processo de busca do desaparecimento, destacam-se as mulheres. São elas que historicamente constituem os principais movimentos de defesa dos direitos humanos, de luta 
contra a impunidade. São elas que, majoritariamente, carregam a foto de seu familiar, dirigem-se aos órgãos públicos, reivindicam, sofrem as ameaças.

Eu continuei na luta, eu continuei na luta, e era malvista por isso, porque eu batia de frente, eu tava lá sempre, entendeu, mas eu sempre deixei claro, eu tô batendo de frente, por causa do meu filho, é meu filho, eu não devo nada a vocês, cansei de mandar recado praquele cara de Parada de Lucas (...) ele foi dentro da minha igreja 4 vezes, numa blazer preta, com 4 homens de fuzil pra me matar. O Furica foi 4 vezes dentro da minha igreja num domingo de manhã, com 4 homens de fuzil pra me matar. E o pastor falou pra ele, ela é uma mulher de Deus, ela tá procurando o filho dela, deixa ela em paz, ela tá no direito dela. Ele falou, eu vou matar ela, ele falou. Eu acho meio difícil hein, porque Deus não vai permitir que tu toque nela não... realmente Deus não permitiu (Mãe de desaparecidocomum de 2005, Vigário Geral).

\section{As mulheres e a sua constituição enquanto sujeito político}

Leite (2008, p. 138) ressalta que as mulheres, especialmente as mães, ocupam um lugar central na vida das favelas/comunidades e desfrutam de uma espécie de "respeito" por parte dos moradores da favela e até mesmo de integrantes dos bandos armados. Por essa razão, tem mais possibilidades de "negociação", no que diz respeito à proteção de seus filhos. De acordo com Geertz (apud LEITE, 2008, p. 139), o reconhecimento generalizado dos "laços primordiais", permite às mães acionar uma esfera de valores que, em certos contextos, é reconhecida como legítima.

Vale ressaltar que, o papel socialmente hegemônico estabelecido para as mães, como cuidadoras por excelência e portadoras do amor maior por seus filhos, é uma construção social. Badinter ${ }^{5}$ (1985) ressalta que o amor materno não constitui um sentimento inerente à condição de mulher, pois ao examinar dados históricos, a autora mostra que nos séculos XVII e XVIII o próprio conceito do amor da mãe aos filhos era outro: as crianças eram usualmente entregues às amas, para que as criassem, e só voltavam ao lar depois dos cinco anos.

A autora salienta que o conceito de maternidade tem sido utilizado de forma ambígua, pois remete ao mesmo tempo a um estado fisiológico momentâneo, a gravidez, e a uma ação a longo prazo, a maternagem e a educação.

\footnotetext{
${ }^{5}$ Badinter (1985) afirma: "Os carinhos maternos, a liberdade do corpo e as roupas bem adequadas testemunham um novo amor pelo bebê. Para fazer tudo isso, a mãe deve dedicar a vida ao fillho. A mulher se apaga em favor da boa mãe que, doravante, terá suas responsabilidades cada vez mais ampliadas. Nesse final do século XVIII, é em primeiro lugar a higiene e a saúde do bebê que exigem a atenção da mãe".
} 
O processo da maternagem, que ganhou força a partir do século XIX em nossa sociedade, se apresenta quase como hegemônico. Alguns setores da sociedade de uma forma geral tendem a agir com preconceito em relação a mulheres que optam em não ter filhos, embora se observe uma progressiva mudança no que se refere a essas questões, haja vista a incorporação de novas configurações familiares, como as famílias recompostas, com diversas gerações em convivência, famílias monoparentais, entre outras.

A maternagem, a devoção, o sentimento de cuidado, de proteção, ao longo do tempo ganhou uma força simbólica, dirigida às mulheres, em especial às mães. As mães são ligadas à origem, à natureza, à pureza e daí a sua ligação com algumas correntes religiosas, especialmente à figura de Nossa Senhora, mãe do "Salvador" e de todos os homens e mulheres.

As mulheres são aquelas que se lançam no âmbito público, não somente movidas pela sua missão de lutar pela justiça, para honrar a morte ou esclarecer as circunstâncias do desaparecimento de seu familiar ou dos familiares das demais mulheres que passam por processo semelhante. A idéia de missão remete a algo que é inerente, natural e definitivo.

A ocupação do espaço público pelas mulheres é reforçada pela maternagem, por esse sentimento de devoção, construído socialmente. Além da relação íntima de afeto construída, as construções sociais reforçam a especificidade de uma dedicação diferenciada da mãe, mulher, aquela que gerou, que "ama o filho acima de todas as coisas" e que seria capaz de salvá-lo, em detrimento da sua própria vida.

(...) eu já perdi meus 2 maridos, e nada se compara ao que eu sinto pelo meu filho, tá, porque é o que a Vera costumava dizer, quando a gente perde pai e mãe nós somos órfão, que nome se dá pra uma mãe que perde um filho? Não existe nome... (Mãe de desaparecido comum de 2005, Vigário Geral).

Nesse sentido, é possível observar que as mulheres integram mais as organizações do que os homens e esse fato é naturalizado, conforme o depoimento abaixo.

Sim, mulher é mais corajosa, mais destemida, homem é mais frouxo, em algumas situações fica medindo como vai poder chegar a uma situação, a mulher não, não é à toa que na maioria das organizações tem mais mulher, homens são mais centrados (...) (Militante e irmã de vítima sobrevivente da Chacina da Candelária de 1993) ${ }^{6}$.

\footnotetext{
${ }^{6}$ Foi entrevistada a irmã de um sobrevivente que milita na área de direitos humanos com familiares de mortos e desaparecidos.
} 
Em uma perspectiva desnaturalizante, a maior presença feminina pode ser relacionada às construções sociais em torno do papel da mulher, que historicamente tem assumido mais a funções do cuidado, e à ausência masculina dentro da família, a única responsável pela provisão da família.

[O marido] Ajudava em nada, bebia muito, ficava muito nervoso, não ligava pros filhos, era biscateiro, pedreiro e tudo, mas sustento pra casa era terrível, sobrava nada, era eu que era o pai e mãe junto, eu fazia tudo, eu criei tudo sozinha... (Mãe de desaparecido comum de 1976, São João de Meriti).

A coragem atribuída mais à mulher do que ao homem tem relação com o campo de possibilidades mais ampliado para as mulheres, de acordo com a análise de Geertz.

Acho que a gente é muito especial, sabe por quê? Porque Deus, ou [aquilo em] que vocês acreditem, ou a força interior que a gente tem... (...) a gente que é mulher (...) consegue que... por exemplo, quando eu fui lá na 'boca de fumo' (...) o meu marido foi, mas ficou quietinho no canto. Só quem falou fui eu (Depoimento de moradora In: LEITE, 2008, p. 138).

Araujo (2007) destaca que, é a partir do tradicional papel de mãe reservado à mulher, que as mães entram no campo político para denunciar a maternidade partida (p. 70).

\footnotetext{
Nós éramos onze mães e hoje realmente somos dez mães, porque não temos um pai presente. E meu marido, um escrivão de polícia, (...), em momento nenhum saiu para me acompanhar, para me dar um apoio. Porque a minha filha saiu de mim. Ele achou que eu não devia mais procurá-la, [porém] eu vou procurar enquanto viver. Porque ele não é da minha família, mas a minha filha é, saiu de mim. Então eu tenho o direito de procurar. $\mathrm{E}$ as outras mãezinhas também lutando muito sem os seus maridos, sem os seus companheiros, mas estamos ali na luta. Temos essas assim um pouco afastadas, mas sempre que nós temos uma reuniãozinha elas vêm, embora com muito medo. E têm também muito medo de falar, mas elas sempre estão presentes e querem saber o que aconteceu com os filhos delas. Então, nós, assim, abraçamos aqueles filhos e hoje eu digo que eu sou mãe de todos os jovens. Porque eu tenho o maior cuidado, eu não admito que um policial chegue perto de' um jovem e aborde ele em má situação. Eu estou brigando, eu brigo mesmo, eu sou uma brigona da Cinelândia. (Vera, Mães de Acari, 2006 In: ARAUJO, 2007: 71).
} 
Araujo (2007), em referência à Das $(1995)^{7}$, ressalta os movimentos realizados pelas familiares de vítimas de violência, especialmente no Rio de Janeiro, que se constituem como agentes sociais, políticos e:

(...) passam a interpelar o Estado em razão do sofrimento provocado seja pela violência direta e aberta do Estado, seja pela incapacidade deste Estado de promover a segurança pública, sobretudo no que diz respeito aos territórios sócioespacialmente segregados, que passam a sofrer com o exercício da força protagonizado pelas facções criminosas ligadas ao tráfico de drogas, particularmente nos territórios das favelas. O sofrimento e a dor têm seu papel na criação de 'comunidades morais'; ao exigirem justiça e ao se relacionarem com o sistema burocrático e jurídico do Estado, tais comunidades são deslocadas do mundo privado e "criadas" como comunidades políticas, passando a questionar a legitimidade de um Estado incapaz de monopolizar a violência. Nesse sentido, violência não é só destruição, influi na construção de novas identidades sociais e políticas (p. 13).

A partir de uma leitura da obra do francês Charles Baudelaire e tendo como aporte teórico-conceitual as análises de Freud (sobre o choque e a experiência traumática), de Simmel (sobre os estímulos da metrópole na vida mental do indivíduo) e de Marx (sobre o fetichismo da mercadoria e da alienação), Walter Benjamin efetua uma análise da experiência urbana. Para ele, o meio urbano é o lugar por excelência de realização do capitalismo, e o fetichismo da mercadoria passa a moldar as relações sociais de tal forma que os sujeitos só respondem ao estado de alienação através do choque. A experiência urbana se assemelharia à experiência do operário com a máquina: “À vivência do choque, sentida pelo transeunte na multidão, corresponde a 'vivência' do operário com a máquina" (BENJAMIN, 1989: 126 apud Araujo, 2007:14).

(...) o rapaz que tava do meu lado falou, calma, você ainda não chegou lá pra saber... eu fui caminhando, menina parecia que meus pés tava pesado, porque eu não chegava nunca (...) Ele não precisou de abrir a boca pra falar uma palavra... eu olhando dentro dos olhos dele... parece que eu senti o pavor, o terror, o medo, não sei, eu senti uma coisa muito estranha... daquele momento em diante eu não lembro mais do que tinha acontecido, quando eu voltei a mim, eu já estava lá dentro da Delegacia, eles me dando uma água com açúcar, eles me fazendo voltar ao normal... a menina que tava lá, uma das mãe falou pra mim que eu perguntei o que tinha acontecido, se eu tinha desmaiado, ela disse que não, disse que eu fiquei dura (...) eu

\footnotetext{
${ }^{7}$ A antropóloga Veena Das (1995) seleciona um conjunto heterogêneo de "eventos críticos" como o desastre industrial de Bhopal, a Partição da Índia, a prática do sacrifício feminino entre os hindus e o apelo ao exercício da violência entre os militantes Sikh, para compreender algumas das categorias centrais na política indiana como as de "vítima", "memória", "tradição", "honra", "sacrifício" e "pureza" (apudARAUJO, 2007: 12).A autora acima destaca, a partir da leitura de Benedict Anderson (1991), que os eventos críticos permitem explicar as transformações políticas contemporâneas, haja vista que as "comunidades" em choque com o Estado se constituem como agentes políticos e, ao mesmo tempo, são reconhecidas como "vítimas", provocando um movimento do Estado de reconhecimento de seus interesses. A princípio esses agentes não estão ligados a um território local exclusivo, mas se constituem a partir do sentido que Anderson dá à expressão "comunidades imaginadas" (apud ARAUJO, 2007: 13).
} 
só lembro que eu tinha olhado pra dentro do olho do menino e.... (choro)... eu senti dentro de mim o grito pra fora, eu senti o grito do meu filho (Mãe de desaparecido comum de 2005, Vigário Geral).

Dessa forma, a passagem do momento do que denominarei vida comum, de inserção pública modesta, para a vida predominantemente pública, se dá por meio do evento traumático, do choque. Ponto significativo é que essa inserção é condição para alcançar outro patamar na esfera de direitos; em nosso caso específico, o das familiares de desaparecidos, o esclarecimento dos fatos, a punição de agentes violentos, o direito de enterrarem seus entes queridos.

Após o desaparecimento, os movimentos das familiares podem se chocar com diversas situações e atores sociais: a ação violenta tanto da polícia como dos traficantes de drogas, os contatos com as várias entidades de defesa de direitos humanos, a peregrinação pelos órgãos públicos, o diálogo com a imprensa, o contato com pesquisadores, com políticos e autoridades públicas (ARAUJO, 2007: 18).

(...) aí vai pra Brasília, teve aquele Mulheres da Paz, eu participei junto das meninas, e foram quase 200 e tantas mulheres pra lá, 300 e tantas, e vai pra Brasília, e volta, e vai e volta, que era tudo pago pelo governo né, que a Cristina que via isso tudo e as menina, né, a Gracilda, e fala com o deputado, fala com o secretário dos direitos humanos, fala com um, fala com outro, e passa 1 mês, passa outro, e você entrega documento, entrega depoimento, entrega papel que mostra que realmente os policiais tiveram naquele local (Mãe de desaparecido comum de 2005, Vigário Geral).

Eu tive que falar abertamente com a imprensa toda... ele era conhecido... aí eu tinha que lutar pelas minhas filhas... eu queria enterrar ele, mas não consegui nada... chorei muito, desesperei... ficou nisso... muito cruel mesmo (...) (Esposa de desaparecido político de 1975, Rio de Janeiro).

Nessa perspectiva, o choque é fator que provoca a ruptura com o cotidiano comum e que permanece, de maneira menos intensa, nas interações derivadas da inserção pública, especialmente nos casos em que não é possível avançar nos esclarecimentos do desaparecimento.

Sair da esfera privada, falar do seu filho ou ente querido, do que aconteceu ou pode ter acontecido, dos seus anseios e sonhos, significa não somente tornar a existência do filho conhecida/perpetuada para a sociedade e para si, já que a pessoa desaparecida não pôde continuar seus projetos, mas lembrar o seu desaparecimento, tentar esclarecer as 
circunstâncias, localizar o seu paradeiro e, se possível, punir os culpados, nos casos do desaparecimento forçado.

Nesses casos, a defesa da honra do familiar é um aspecto fundamental, que tem como objetivo retirar, perante a sociedade, uma culpa que, imputada ao seu ente querido, poderia “justificar” a situação de violência sofrida ou ainda minimizar o seu valor humano. Daí a preocupação de muitas mulheres em afirmar de forma reiterada que seus familiares não tinham envolvimento com atividades ilegais ou que não eram usuários de drogas.

Outra dimensão, nos casos de desaparecimento intencional, é retratar que não houve abandono por parte da pessoa desaparecida, poisa dor não poderia ser produzida pelo familiar de forma voluntária.

Nesse movimento, algumas mulheres, cujos familiares foram desaparecidos, saíram do espaço privado pela primeira vez, no sentido em que suas atividades pessoais eram restritas às tarefas domésticas.

(...) naquela época eu só apoiava, depois de mais velha eu ia no Grupo Tortura Nunca Mais e tal, mas naquela época eu era dona de casa, cuidava das filhas, 3 se formaram.

(...) eu sei quem foi pego, quem foi pego e morto, não apareceu corpo nem nada... eu procurei muito direitos humanos, sempre fui batalhadora... mesmo naquela época... se ele perdeu a vida, eu não tenho nada a perder, não era vinculada a política... era dona de casa... tanto que o Modesto foi meu advogado... ele me falou... você pode procurar, você pode entrar de cabeça... procurei no sindicato, e tudo mais, não encontrei nada... até hoje... uma dor tremenda... (Esposa de desaparecido político de 1975, Rio de Janeiro).

Algumas mulheres estavam no mercado de trabalho formal ou informal, mas sem um histórico de reivindicação de direitos. Em alguns casos, antes do desaparecimento de seu familiar, a sobrevivência por meio de uma dura jornada de trabalho constituía a sua principal inserção na esfera pública.

Eu trabalhava no Unibanco de auxiliar de limpeza, né, e copeira, e trabalhava nos finais de semana, sábado e domingo eu era babá, entrava no sábado de manhã e saía na segunda-feira de manhã já pra trabalhar no banco, que eu trabalhava de segunda a sexta... e estudava à noite (Mãe de desaparecido comum de 2005, Vigário Geral).

Outras já atuavam com esse enfoque mais reivindicativo, na sua grande maioria no que se refere ao acesso a direitos sociais básicos, como saúde, educação, emprego, entre outros. 
Ele... não trabalhava porque ele tava com 20 anos... só tem que eu corria aqui embaixo pra dar emprego pra ele... até já fui no governador (...) uma semana antes de acontecer isso eu fui no governador (...) Aí fui com ele pra ver o primeiro emprego, aí foi que eles responderam lá que... falou pra ele: Você pensa que é assim? Tem muita gente precisando mais... na sua frente... vocês tem que esperar... Foi quando que a única solução era vender doce (Mãe de desaparecido comum de 2003, Queimados).

Alguns movimentos de mulheres se tornaram emblemáticos. Freitas (2000) sugere que o envolvimento das Mães de Acari ${ }^{8}$ nas lutas por justiça e esclarecimentos - a partir do que seria seu lugar na esfera privada - possibilitou a construção de uma nova identidade relacionada às suas práticas na esfera pública, o que impactou também a dimensão privada, devido à circulação nos diferentes espaços (ARAUJO, 2007, p. 73).

Contudo, mesmo aquelas que se moviam numa direção mais reivindicativa, falar do desaparecimento do seu familiar nem sempre é um processo que se dá de forma imediata. Muitas vezes é necessária a interlocução de outros atores como uma etapa para o seu processo de assunção do espaço público.

\begin{abstract}
Não, eu andava em coisa quando tinha manifestação (...) reunião, esses negócios, tudo eu ia, só que eu não falava né, eu não tinha coisa de falar, elas que falavam por mim, quando a reportagem perguntava, o que aconteceu com ela: ah não, o filho dela que sumiu, a gente tá resolvendo... Quer dizer, então ficava sempre... quando eu fui pra $\mathrm{CESeC}^{9}$ [Centro de Estudos de Segurança e Cidadania - Universidade Cândido Mendes] (...) foi que a Barbara e o coisa falou: a senhora que tem q falar e não os outros falar pra senhora, foi que eu comecei a acordar e era tarde, que eu comecei a falar o que aconteceu com o meu filho e to falando o que tá acontecendo,
\end{abstract}

\footnotetext{
${ }^{8}$ As mães das vítimas da conhecida Chacina de Acari de 1990 ficaram conhecidas nacional e internacionalmente como Mães de Acari. A nomenclatura refere-se principalmente às mães que buscaram esclarecer as circunstâncias do desaparecimento de seus filhos. Em 21 de julho de 1990, 11 jovens foram passar o fim de semana em um sítio em Suruí, Magé, na Baixada Fluminense, estado do Rio de Janeiro. Passado o fim de semana, decidiram permanecer mais alguns dias no local. Segundo depoimentos, na noite do dia 26, seis homens encapuzados entraram no sítio dizendo que eram policiais. Após conversarem com três dos jovens no sítio, teriam levados todos numa Kombi e no carro de um dos jovens. Há várias versões. Uma delas é que depois de torturados, foram colocados numa van que teria sido incendiada. Outra é a de que os corpos teriam sido jogados aos leões que eram mantidos no sítio de um policial civil, próximo ao sito onde se encontravam inicialmente. As Mães de Acari comparadas às Mães da Praça de Maio, da Argentina, tem apoio da Anistia Internacional. Em 1993, uma das mães mais atuantes, Edméia, foi brutalmente assassinada na saída de um presídio no Rio de Janeiro. Segundo relatos, ela acabara de receber informações que teriam sido fundamentais para o esclarecimento da chacina (SOARES et al, 2009).

${ }^{9}$ A entrevistada participou do Projeto de Apoio a Familiares de Vítimas de Chacinas, que tinha como "um dos muitos desafios contribuir para criar canais de vocalização, de pressão e de identificação mútua sem reproduzir o mecanismo perverso, cada vez mais recorrente, de hipervalorização e de atribuição de notoriedade ao lugar social de vítima e, portanto, de seu aprisionamento na condição de pessoa vitimada" (SOARES et al, 2009, p. 14). O Projeto teve como um de seus desdobramentos o livro Auto de Resistência, que se divide em duas partes: a primeira apresenta os casos de forma individual e a segunda descreve os obstáculos de quem não se propôs ao silêncio, as conquistas obtidas e o convívio com outras familiares de vítimas da violência. A noção de vítima, bastante polêmica, pode atuar em dois pólos: como forma de geração de visibilidade à luta dessas mulheres, e por outro lado, o aprisionamento numa condição passiva e redutora de possibilidades.
} 
porque eu sei tudo que aconteceu com meu filho, até hoje, só tem que se tivesse uma investigação coisa já tinha resolvido isso (Mãe de desaparecido comum de 2003, Queimados).

As mulheres, no processo pós-desaparecimento, podem caminhar em uma linha contínua e/ou relacional: a vivência da violência em uma perspectiva individual, de não compartilhamento e de introspecção; ou a transformação da sua perda numa questão pública, por meio da exposição da sua dor, seja com o intuito de buscar justiça, esclarecimentos ou a localização do seu ente querido. Nesse sentido, como um passo à frente, transforma a sua perda em uma causa social, que seria a transcendência radical da sua experiência individual e a assunção de uma vivência compartilhada com outros familiares e com causas semelhantes.

A vida pós-desaparecimento com base em um movimento mais solitário e individual, pode se configurar pela opção por não tornar esse episódio traumático uma causa pública/social ou mesmo de não compartilhamento da dor ou dos efeitos físicos, psicológicos, sociais que a experiência da perda pode ocasionar.

Quando fui dar parte no DPCA, começaram a divulgar as fotos dele, eles indicaram a gente pra esse lugar que falaram que ia ser divulgado, não lembro o nome, a gente andou por vários lugares... eu nunca fiz parte de nenhuma reunião, nenhuma organização, não conheci nenhuma mãe com problema parecido, não...

Não, hoje em dia eu só penso em ficar sozinha, sozinha... minhas filhas falaram até que eu to ficando velha, que não saio, deixa eu... não tive outro companheiro, moro com meus filhos.. minha mãe sente falta, ela vai pra igreja, pede... ela não mora mais perto de mim... (Mãe de desaparecido comum de 2001, Anchieta).

Araguaia ela foi, [minha mãe] conheceu várias pessoas que conheceram o Guilherme, pessoas do local, que na época estavam vivas, hoje deve ter poucas pessoas... pra ela foi duro, ela começou a perder a saúde, pressão alta, derrame na vista, ficou cega de um olho, era jovem, 59 anos... (Irmã de desaparecido político de 1973).

(...) meus pais tavam morando aqui, nesse apartamento, quando eu casei ele veio no dia seguinte, ele gostava de Petrópolis, tanto que ele gostava da cidade, e não pôde aproveitar quase nada, eu fiquei no Rio, casei, fui morar em Copacabana, depois no Leblon, e meu pai em abril já ficou doente, e minha mãe viúva, sem ter irmãos, sem ter família nenhuma, aí ela foi morar comigo, voltou pro Rio, veio comigo... foi terrível pra ela, perdeu marido e o filho, foi uma barra, mas ela foi forte... (Irmã de desaparecido político de 1970).

A opção pela individualidade da dor pode também ser motivada pela necessidade de prosseguir com as atividades diárias, principalmente o trabalho:

(...) voltei a trabalhar em casa de família, quando eu conheci a Cristina, em Ramos, fiquei coisa de 1 mês em casa, ai voltei a trabalhar, sempre continuei, me separei do 
pai dos meus filhos, ai tinha que botar as coisas dentro de casa... tem que trabalhar pra me sustentar e a filha, né. Mudou muita coisa... (Mãe de desaparecido comum de 2001, Anchieta).

Independente do encaminhamento direcionado pela familiar, as mulheres carregam em si um testemunho, seja sobre os detalhes da vida, da história, as possibilidades da morte, a dor e o que se espera dos outros, do futuro. O testemunho das familiares tem um potencial significativo, individual e coletivo. Individual no sentido do que se faz com ele e de que forma ele se confunde com os efeitos do episódio traumático. Coletivo porque pode se somar a outras experiências e pode ser um vetor de transformações de histórias até então apartadas do seu cotidiano e da sua esfera de elaboração e reconhecimento.

Araujo (2007) ressalta a passagem do luto à luta, do tempo do choque, marcado pela dor da perda e do desaparecimento, para um tempo da política onde essa dor é transformada em capital político, através da elaboração da denúncia pública por parte das mães e das entidades que lhes davam suporte (p. 31). Se pensarmos no luto de forma processual, a passagem à luta se dá de forma também processual. Outro ponto a ser ressaltado é que se entende a política em sentido amplo, nos termos gramscianos, como catarse.

A concepção ampla de política gramsciana atenta para a importância da política na constituição dos seres sociais. O conceito de política gramsciano abrange duas concepções. Em seu sentido "amplo", como "catarse", a política é um elemento que atravessa todas as esferas do ser social. E como "catarse", indica a passagem do momento identificado com a liberdade. Nessa concepção, a política é concebida como instrumento de criação, de elaboração de consciência para que a "classe social" possa se tornar hegemônica na sociedade $^{10}$ (COUTINHO, 2003). No sentido restrito, o conceito aparece como o "conjunto de práticas e de objetivações que se referem diretamente ao Estado, às relações de poder entre governantes e governados. Se, em sua primeira acepção a política pode ser considerada um momento ineliminável da estrutura ontológica do ser social, nessa segunda acepção ela aparece, ao contrário, como algo historicamente transitório" (COUTINHO, 2003, p. 93).

Gramsci, diferentemente de Marx, Engels e Lenin, presenciou a intensificação dos “processos de socialização da participação política". A formação de novos sujeitos políticos

\footnotetext{
${ }^{10}$ A acepção restrita gramsciana de "política" a apresenta como algo transitório no decorrer da história, que "será superada dialeticamente, (...) elevada a nível superior na sociedade comunista" (COUTINHO, 2003). O caráter histórico e, por essa razão, transitório, tem origem na divisão da sociedade em classes e tem seu fim com o advento da sociedade comunista e a conseqüente extinção das classes sociais.
} 
possibilitou a Gramsci a ampliação da teoria de Estado elaborada anteriormente por esses pensadores.

Gramsci, ao ampliar o conceito de Estado, pensa o termo sociedade política representado pelo Estado-coerção aliado à sociedade civil, esta formada pelas diversas organizações sociais e coletivas autônomas em relação àquela. No pensamento gramsciano, a supremacia seria o momento em que a hegemonia e a dominação, o consenso e a coerção, a direção e a ditadura são unificados, mas a disputa pela supremacia dependeria da autonomia das esferas superestruturais e do grau de correlação de forças entre as classes sociais.

De acordo com Acanda (2006), a teoria da hegemonia de Gramsci tem como ponto de partida a questão da relação entre política e cultura. Com o significado gnosiológico do princípio da hegemonia, Gramsci ressalta a sua ruptura com a concepção liberal e afirma a dialética da sua interpretação sobre política ${ }^{11}$ - a relação orgânica entre política e cultura, entre poder e saber. Nesse sentido, Gramsci pensa os processos de dominação e o poder, analisando-os também na esfera cultural ${ }^{12}$.

A denúncia do desaparecimento pode ser um caminho para a sua politização. Boltanski (1990) afirma sobre a construção da denúncia pública e identifica, no sistema de denúncia, três atores: uma vítima, um denunciante e um perseguidor. $\mathrm{O}$ autor argumenta que quem denuncia algo ou alguma coisa deve ser capaz de convencer as outras pessoas, associálas a seu protesto, mobilizá-las. Para isso é necessário não só lhes assegurar que lhes diz a verdade, mas também, que ela merece ser explicitada, na medida em que para corrigir uma injustiça é preciso acusar o agente (o ser individual ou coletivo) responsável por ela. $\mathrm{O}$ autor de uma denúncia pública demanda, com efeito, ser seguido por um número indefinido, mas necessariamente elevado, de pessoas (por "todos"; por "todos aqueles que contam"; por "todos os homens de bem", etc.). A causa que ele defende encerra uma pretensão à universalidade. Parte-se de um caso singular, mas exemplar, que diz respeito a todo mundo (apud ARAUJO, 2007: 60).

\footnotetext{
${ }^{11}$ Segundo Coutinho (2003), no pensamento gramsciano existe uma centralidade da política, pois se tende a relacionar todas as esferas do ser social com o campo político, "a política como elemento real ou potencial ineliminável" (p. 91).

12 A teoria gramsciana sobre o poder apresenta-se em contraposição às concepções liberal e marxista economicista da II Internacional. Na concepção liberal, o poder é considerado um bem, uma mercadoria que concebe a figura de um "sujeito primário, dotado de direitos naturais e poderes" (idem, 202). O poder é visto como algo negativo, veículo da repressão. Na concepção marxista também se presencia a negatividade do poder, pois se enfatiza o seu caráter de repressão e violência. O poder é concebido como o Estado, e a sua função seria apenas a manutenção das relações econômicas existentes.
} 
A fase de elaboração e construção da denúncia pública é um importante momento na produção de um acontecimento enquanto acontecimento político, ou seja, o fato ganha uma dimensão explicitamente política e torna-se uma causa. O momento da denúncia pública aparece como um vetor de impulso para o acontecimento político, uma disputa e uma busca pela legitimação pública dos interesses por parte do denunciante (apud ARAUJO, 2007, p. $65)$.

Araujo (2007) identifica no caso das Mães de Acari cinco estratégias utilizadas para a denúncia pública: os depoimentos-testemunhos das mães em eventos diversos; as práticas de luto reivindicativas de justiça; a denúncia internacional através da Anistia Internacional; a denúncia via meios de comunicação; e o registro da denúncia em livros (p.65).

As mulheres de uma forma geral são mais reconhecidas e, em virtude disso, possuem mais espaço para essa inserção. Porém, esse espaço não é imune a riscos.

Muitas famílias são obrigadas a conviver com os assassinos/suspeitos de serem os agentes que provocaram o desaparecimento, e em muitos casos, com o local onde ocorreu o episódio traumático, na medida em que não possuem recursos financeiros ou não vislumbram a possibilidade de sair daquela localidade, onde têm laços afetivos e de pertencimento ${ }^{13}$. Nesse sentido, é possível observar uma relativa impotência dessas famílias, no que se refere à interrupção dessa convivência para com os assassinos/local onde ocorreu o desaparecimento/morte, e em relação à manutenção de denúncias sistemáticas, pois qualquer movimento nesse sentido pode comprometer a sua própria segurança (CANO, 2009). O autor ressalta que esse quadro é conhecido na psicologia com o termo de 'indefensão aprendida' (learned helplessness'), onde a passividade pode ser a única opção.

Por outro lado, apesar da impossibilidade de ampliarem o seu escopo de proteção, mantém a sua denúncia e a busca pelos esclarecimentos do desaparecimento.

(...) porque minha proteção era Deus, protegida por essas pessoas, porque eu vi que a minha vida também tava ameaçada ali. Eu tive uma vez que eu tava dentro de Lucas com Vigário, o Furica tava do outro lado com uma mira-laser mirando no meu peito pra me matar, e eu invadindo a comunidade, aquela inchada, tem uma

\footnotetext{
13 "Para o coordenador do Centro de Estudos e Ações Solidárias da Maré (Ceasm), Jaílson de Souza, a subnotificação nesses casos acontece porque as famílias continuam morando nas favelas onde seus filhos foram mortos e porque elas não acreditam que a polícia vá investigar e prender os culpados: Depende de onde é o desaparecimento. Quando é na própria favela onde mora, é natural que a família tenha medo do conflito com a quadrilha e até mesmo da polícia, que muitas vezes não é a oficial, mas sim policiais corruptos que aproveitam para extorquir traficantes”. Jornal O Globo, 07 de maio de 2006. Tráfico some com corpos e afeta estatísticas.
} 
reportagem que tem no jornal, eu pedi inchada na comunidade de Vigário Geral, eu cavando e a reportagem fazendo e eu cavando ali e gritando e as mães tudo com rosto coberto e eu mostrando a cara, então eu fui uma afronta pra eles, fui uma afronta pra PM, fui uma afronta pros traficantes, porque várias vezes o comandante teve lá na porta da casa da minha mãe, batendo nos portão lá não sei procurando o que, uma vez eu fui lá na casa da minha mãe, que eu fui lá escondido, e o meu menino que eu criei de 12 anos, ele chorava, ele dizia assim, mãe, ele tá lá do outro lado da rua, ele veio pra te pegar, pula o muro, e eu pular muro! E eu ligar, C., eu tô escondida, eles vão me matar! De eu alugar casa em Caxias, de eu olhar pela coisa e ver Carlos do décimo sexto, o que ele tava fazendo em Caxias? De madrugada, de eu pular muro de madrugada, de eu vir parar no centro da cidade 3, 4 horas da manhã sem ter onde dormir, de eu dormir na praia, de eu não poder voltar pro lugar onde eu tava, entendeu. Eu tive 16 endereços diferentes. Quando eu fui parar em Brasília, pedir pros Direitos Humanos, que eles queriam me colocar no Programa de Proteção à Testemunha, eu não aceitei, porque se eu fosse pro Programa de Proteção à Testemunha quem ia procurar meu filho? Minha família não ia, que minha mãe tinha medo, minha família tinha medo. Então quem ia procurar meu fillho? (Mãe de desaparecido comum de 2005, Vigário Geral).

\section{Efeitos do desaparecimento}

Algumas mulheres são sujeitas a um risco permanente e a ameaças que podem reforçar ou bloquear o seu movimento na direção da busca por justiça. As ameaças podem ser direcionadas diretamente à mulher ou aos seus familiares, muitas vezes com graus de parentesco muito próximo ao do desaparecido ou até mesmo semelhante. No relato abaixo, a ameaça era direcionada aos filhos da mulher que já possuía um filho na condição de desaparecido.

(...) ia lá na minha porta me ameaçar (...) que era pra mim parar de ta andando aqui embaixo, que ia sumir com os outros meus filhos (Mãe de desaparecido comum de 2003, Queimados).

(...) na hora que eles entraram pra fazer reconstituição, tinha 2 meninas brigando, por causa de um traficante lá, um bandido. Uma era mulher do cara, e a outra não era. E elas tavam caindo no pau, e elas brigaram logo na rua onde eu dormia, e elas brigando, e entrava pra dentro de casa, quebrando tudo, do ladinho da casa onde eu dormia, e aí a porta tava encostada (...) meu filho tava dormindo, a polícia invadiu a casa que tava toda quebrada e invadiu a casa onde meu filho tava dormindo, só que a documentação do meu filho tava toda na casa da minha mãe, onde eu morava (...) eles pegaram meu filho e algemaram meu filho, quando eu cheguei eu fiquei louca, que eu vi meu filho algemado, meu filho era trabalhador, eu fiquei em pânico com aquilo, eu falei, meu filho trabalha desde 14 anos de idade, que ele trabalhava no BNDES desde 14 anos de idade meu mais velho, na época ele tava trabalhando na Rede Globo, meu filho é trabalhador, Cristina Leonardo ficou louca, arrumou advogado, carregaram meu filho algemado, botaram naquela parte de trás do carro da CORE, e eu sei que eu agarrei no pescoço do policial, e agarrei no volante do carro pra não sair dali com meu filho que meu filho não era bandido, e grudei o pescoço do polícia porque eu não aceitava aquilo, eu já tava sofrendo, como eles ia carregar meu filho que não tinha a ver com nada (...) meu medo era tão grande de perder aquele filho, que eu me apeguei... (choro)... eu tenho um amor, meu Deus, 
misericórdia, foi o que me sobrou, vocês não vão tirar ele de mim, e eu sei que eles tiraram meu filho da caçapa, desalgemaram ele, e colocaram ele dentro do carro da polícia, eu não queria deixar levar ele, e tanto que tem uma foto no jornal O Povo, eu subindo na frente do carro da CORE, pra não deixar eles ir no carro com meu filho, e eu sei que nessa época eu fui ameaçada por policiais (...) (Mãe de desaparecido comum de 2005, Vigário Geral).

As ameaças podem não ser declaradas, mas realizadas meio do terror psicológico e de episódios de risco:

\begin{abstract}
Não de telefonemas, entendeu, mas de olhares... através de advogados deles... tanto que quando eu tava nas primeiras audiências, que eu e ele fomos chamados,a promotora falou pro Adriano não andar sozinho a noite, porque tão querendo pegar ele, podem querer botar bagulho no carro numa blitz, aí ele parou de andar de bicicleta, ficou bem dentro de casa, não ficava pra lá e pra cá, não saía de carro aberto, ele ficou bem visado, até mandou ele sair um pouco do Rio, ele saiu... ela tava preocupada. O carro dele pegou fogo ele dirigindo, ninguém sabe o que foi, eu nem mandei pra pericia, mandei consertar e acabou... (Mãe de desaparecida comum de 2008, Barra da Tijuca).
\end{abstract}

Essa convivência forçada, motivada muitas vezes por insuficiência de recursos para constituírem residência em outro local, intensifica a experiência da dor.

Quando eu vi que tava tudo mais assentado, depois que eles tomaram lá, e que mandou avisar que não ia mais fazer nada com as mães, porque eu vi que tinha mães dentro na comunidade e eles não fizeram nada, aí eu vi que eles não iam fazer nada com ninguém, aí o Jorge voltou pra lá.

(...) eles já tavam morando dentro da comunidade, com a comunidade com os cara que seqüestraram eles, e aí eles foram pro julgamento com medo... porque ameaçaram eles lá dentro, porque tinha família lá, tudo lá dentro... tipo assim, vocês vão pro julgamento, olha o que vocês vão dizer lá, tua família tá aqui dentro, porque já era os caras que tavam comandando lá, que seqüestraram eles... (Mãe de desaparecido comum de 2005, Vigário Geral).

As famílias de desaparecidos, em especial aquelas que são mais desfavorecidas economicamente, ficam mais sujeitas a essa convivência (com os supostos agentes produtores do desaparecimento e com o possível local), o que pode maximizar o trauma e os danos oriundos da perda, além dos riscos da manutenção de denúncias sistemáticas.

Araujo destaca:

Edméia da Silva Euzébio, 47 anos, uma das Mães de Acari, mãe de Carlos Henrique Silva Euzébio, foi a primeira mãe de Acari a depor sobre a chacina que abalou a sociedade brasileira. O depoimento aconteceu no dia 6 de janeiro e uma semana depois, Edméia foi perseguida e morta a tiros no bairro Cidade Nova (2007: 56). 
Contudo, a convivência com os suspostos agentes produtores do desaparecimento, não está restrita às classes sociais mais desfavorecidas. $\mathrm{O}$ encontro com esses agentes pode ser provocado por diversos fatores:

(...) e eu ainda tenho que aturar que os 2 policiais que tavam no local do crime, tão sendo seguranças perto da minha casa, de um centro comercialzinho, onde eu levo a roupa pra lavar, compro a ração dos cachorros, ou seja eu cruzo com eles...quer dizer, to mudando né, tem até uma roupa lá que tem uns 3 meses lá, da última vez que eu fui lá, eu cheguei no cara da tinturaria, a promotora falou pra não ficar provocando, mas não aguento, eu falei, vem cá, quando vocês pegam um segurança aqui, vocês vêem de onde eles vêm, o histórico dele, e ele falou, não, aí eu, eu falei, pois é, vocês tão com segurança um cara assassino, cuidado... nunca mais voltei... e o outro é segurança do Planeta do Chopp, você passa ele tá rindo, te encara... nas audiências, a mulher dele fica me encarando... como você estivesse errado... eles tão certos... aí passam perto de você com cara de santo... uma vez encontrei com eles em Campo Grande, ele e a mulher, parou, me encarou, eu falei, vou sair do carro, estacionamento, esse cara vai me matar aqui e ninguém vai ver, deixei o carro e fui embora... tudo isso é desgastante, você vê eles soltos, a justiça não anda... você acha que no final a justiça dá privilegio aos assassinos, você que é correto, só perde, só perde...

(...) agora diz que o perigo é quando acabar tudo, né... que aí que eles podem vir em cima da gente, né... se for condenado, os amigos, né... começaram a fazer blitz na esquina da minha rua, rua sem saída... coisas estranhas, não tem por que fazer blitz ali... agora tá sendo segurança ali também... diz a promotora que não podem fazer isso...eles podem ficar provocando, né... a gente evita passar ali, eles ficam com cara de deboche, mas o A. ele é mais estourado, eu já falei mandei evitar... ficar instigando pra que né... eles tem o poder, né... é isso... (Mãe de desaparecido comum de 2008, Barra da Tijuca).

\section{Os efeitos do desaparecimento também são físicos ou psicológicos ${ }^{14}$.}

(...) Eu não conseguia acreditar que tinha perdido meu filho. Era demais para mim. Vivia tomando Diazepan para me acalmar. Acordava de madrugada com o corpo trêmulo. Meu corpo não agüentava. Naquela época eu nem penteava os cabelos. Vivia com uma touca na cabeça (Ana, Mães de Acari. In: NOBRE, 1994).

Toda vez que meu filho era espancado, eu sentia as pancadas no meu corpo (NOBRE, 1994, p. 44).

\footnotetext{
${ }^{14}$ Os impactos da tragédia sobre a saúde das Mães de Acari, como ficaram conhecidas, foi enorme. Tereza teve uma gravidez psicológica. Vera, falecida em 10 de agosto de 2008, desenvolveu uma diabete emocional chegando a ter um dedo amputado, dois derrames, além de perder o marido que resolveu se separar depois do acontecimento. Marilene sofre de uma dor de cabeça que nunca cessa e vive sob medicação. Todas as mães ficaram muito abaladas ao receber uma denúncia de que os filhos teriam sido esquartejados e dados a leões. Márcia Jacintho, mãe do jovem Hanry, assassinado pela polícia, no dia 21 de novembro de 2002, no Morro do Gambá, em Lins de Vasconcelos, conseguiu provar a inocência do filho e condenar os dois policiais responsáveis, mas foi com muita dor e várias entradas no hospital, pois se tornou hipertensa e hoje tem problemas de coração. Dona Izildete, moradora de Queimados, perdeu um filho, desaparecido após uma blitz policial. Após o acontecimento saiu do trabalho e passou a tomar medicamentos e seu outro filho, portador de necessidades especiais, deixou de andar, efeito do sentimento de perda do irmão. (ARAÚJO, Fabio Alves. "Rio: experiência traumática". Jornal do Brasil, 29/03/2009).
} 
Por incrível que pareça, quando faltavam três dias para o Guinho completar 17 anos, meu corpo voltou ao normal. Não sentia mais o inchaço das pancadas. Parece que limpou tudo. Aí eu pensei: acho que o Édson parou de apanhar ou foi morto (idem: 45). (...) Quando os sonhos de tortura terminaram, eu tive outro tipo de sonho. Estava deitada na cama e o Édson chegou. Estava bonzinho, muito bem. Abriu a porta, pulou em cima de mim, em cima das irmãs e foi embora. Essa imagem dele, tão feliz, eu nunca mais esqueci. Daí em diante ele não apareceu mais (ibidem: 49).

(...) às vezes eu passo mal no meio da rua... fui atropelada uma vez, mas só arranhou só...tem dia que levanto boa, tem dia que eu levando com dor de cabeça forte, fico surdinha... (Mãe de desaparecido comum de 2010, Barra da Tijuca).

\section{Uma das Mães de Acari, Tereza sofreu gravidez psicológica:}

O doutor me examinou, fez perguntas e pediu que eu voltasse ao hospital. Quando voltei, me mandaram de novo ao tal ginecologista. Estavam me jogando um para cima do outro. Na minha casa, toda pesada, aquele barrigão, comecei a pensar. $\mathrm{O}$ que é isto? Que barrigona é essa? (NOBRE, 1994, p. 44).

Outra mãe, de Vigário Geral, também convive com os efeitos da violência sofrida:

Faço no posto 11, de hipertensão, eu já tive dois princípio de infarto, e tem dia que eu acordo a minha pressão tá $18,22 \ldots$ e eu vivo a poder de calmante, a remédio de pressão (...) arrumou um psiquiatra pra mim lá na Fundação Oswaldo Cruz, eu fiquei fazendo tratamento lá, depois eu fui pro psicólogo, depois ele me encaminhou pro posto de saúde pra eu continuar o tratamento, eu continuo o tratamento até hoje, pra mim dormir eu tomo Diasepan quando acordo e a noite, a C. me chama de hipocondríaca... (Mãe de desaparecido de 2005, Vigário Geral).

\section{A hipertensão aparece com um dos efeitos mais comuns pós-desaparecimento:}

(...) hipertensão, eu acho que foi provocado por isso, depois que passaram 4 anos eu comecei a fazer tratamento de hipertensão, to fazendo até hoje, só pode ter sido nervosismo... chegou a um ponto que eu não sabia o que era comida... levei uns 5 meses nessa agonia, não me alimentava direito...cheguei a pesar 35 quilos... de tanto sofrimento... (Mãe de desaparecido comum de 1976, São João de Meriti).

A perda também implica na reorganização da vida após o desaparecimento. A reorganização pode inclusive afetar a condição material da familiar.

(...) tudo meu eu tinha que escutar ela, uma era muito ligada a outra em questão de se vestir, e uma época eu tava magrinha, dava pra vestir roupa em comum as duas, comprava pensando nela e ela comprava pensando em mim, e eu sinto muito falta dessa parte também, eu fiquei assim também, a gente era muito amiga, por exemplo, meu marido trabalhava em Brasilia, e ela tinha o quarto dela, e ela não usava o quarto dela, ela tinha que dormir no meu quarto, eu falava, vai pro seu quarto, ela não, quero dormir com você, ai quando o meu marido vinha final de semana, ela já reclamava, e tal, até quando o namorado dela dormia lá, dormia no 
quarto dela e ela no meu quarto, é mole (Mãe de desaparecida comum de 2008, Barra da Tijuca).

Nosso sentimento sempre foi de revolta e impugnação sobre o que tinha acontecido com nosso querido irmão. Nossa família passou a ter muitas dificuldades financeiras, a ponto de não conseguir manter o aluguel da casa em que morávamos, tendo assim que contar com ajuda de outros familiares, tivemos que entregar nossa casa e morar com nossa avó. Tivemos vários constrangimentos (quais constrangimentos?) por conta da perseguição política, tínhamos a sensação de estar sempre vigiada e sofremos varias discriminações de vizinhos e amigos. (Irmã de desaparecido político de 1973).

A dimensão do cuidado é tão marcante que é como se na falta da vida do filho, a sua própria vida não tivesse valor, a não ser na busca em encontrar sentido para a vida do filho.

(...) porque eu falava assim, C., se eu morrer quem é que vai lutar pelo meu filho, e eu ainda falava pra ela, C., eu não tenho medo de morrer, esse meu desespero todo não é esse, de morrer, a coisa é se eu morrer quem vai procurar meu filho? Acaba tudo! Era isso que eu tinha na minha cabeça, entendeu, se eu morrer acabou tudo! (Mãe de desaparecido comum de 2005, Vigário Geral).

O desaparecimento provoca nas famílias a sensação de que ainda épossível a vida, já que não se tem a materialidade da ausência, ou da morte. Esse processo configura o que para as familiares se torna um processo sem fechamento, "uma dor sem fim".

\section{Referências Bibliográficas:}

ACANDA, Jorge Luis. Sociedade Civil e Hegemonia. Rio de Janeiro: Editora UFRJ, 2006.

ARAUJO, Fabio. Do luto à luta. A experiência das mães de Acari. 2007. Dissertação (Mestrado em Sociologia e Antropologia) - Programa de Pós-Graduação em Sociologia e Antropologia, UFRJ, Rio de Janeiro - RJ.

BADINTER, Elisabeth. Um Amor conquistado: o mito do amor materno. Tradução de Waltensir Dutra. Rio de Janeiro: Nova Fronteira, 1985.

BOLTANSKI, Luc. "La dénonciation public". In: L'Amour et la justice comme compétences. Paris: Éditions Métailié, 1990.

CANO, Ignacio. "O desaparecimento de pessoas no Rio de Janeiro hoje". In: SÜSSEKIND, E. (Org.) Memória e Justiça. Rio de Janeiro: Jauá Editores \& Museu da República, 2009. p. 33-46.

COUTINHO, Carlos Nelson. Gramsci: um estudo sobre seu pensamento político. Rio de Janeiro: Civilização Brasileira, 2003. 
FREITAS, Rita C. S. "Mães de Acari": preparando a tinta e revirando a praça - um estudo sobre mães que lutam. 2000. Tese (Doutorado em Serviço Social) - Programa de Pós-Graduação em Serviço Social, UFRJ, Rio de Janeiro - RJ.

LEITE, Márcia Pereira. "Violência, risco e sociabilidade nas margens da cidade: percepções e formas de ação de moradores de favelas cariocas". In: Vida sob Cerco: violência e rotina nas favelas do Rio de Janeiro. Luiz Antonio Machado da Silva (Org.). Rio de Janeiro: Nova Fronteira, 2008.

NOBRE, Carlos. "Mães de Acari”: uma história de luta contra a impunidade. Rio de Janeiro: Relume-Dumará, 1994.

SOARES, Bárbara; MOURA, Tatiana; AFONSO, Carla. (Orgs.). Auto de Resistência: relatos de familiares de vítimas da violência armada. Rio de Janeiro: 7Letras, 2009.

DAS, Veena. Critical events: an anthropological perspective on contemporary India. New Delhi: Oxford University Press, 1995.

Entrevistas realizadas:

Irmã de desaparecido político de 1970.

Irmã de desaparecido político de 1973.

Esposa de desaparecido político de 1975.

Mãe de desaparecido comum de 1976, São João de Meriti.

Irmã de desaparecido comum de 1997, Cabo Frio

Mãe de desaparecido comum de 2001, Anchieta

Mãe de desaparecido comum de 2003, Queimados.

Mãe de desaparecido comum de 2005, Vigário Geral

Mãe de desaparecida comum de 2008, Barra da Tijuca.

Militante e irmã de vítima sobrevivente da Chacina da Candelária de 1993. 


\title{
WOMEN, DISAPPEARANCE AND LOSS
}

\begin{abstract}
This article aims to highlight the trajectory of women after the disappearance. The concept of disappearance developed has as a central element the unknown whereabouts of the missing person by the surroundings. Elements such as the loss, the emptiness and the effects caused by the disappearance are important factors.

Because of the uncertainty inherent to the phenomenon, women Keep the hope of finding the missing person, what makes the processes of mourning impossible. It is also noteworthy that the movements of women in the search for their missing may have a setting more individual or collective.
\end{abstract}

KEYWORDS: Disappearance, Women, Search. 